Ю. В. Козлова, М. О. Корніленко, С. І. Хмель, М. А. Довгаль, В. В. Колдунов, Н. С. Трясак, Г. А. Клопоцький, О. Є. Худяков, А. Ю. Ляліна, Г. М. Хмель-Дунай Державний заклад “Дніпропетровська медична академія Міністерства охорони здоров'я України”, м. Дніпро

\title{
ЗНАЧЕННЯ ЗАГАЛЬНИХ ТА ФАХОВИХ КОМПЕТЕНТНОСТЕЙ У НАВЧАННІ МАГІСТРІВ У ГАЛУЗІ “СТОМАТОЛОГІЯ” НА КАФЕДРІ ПАТОЛОГІЧНОЇ ФІЗІОЛОГІЇ ДЗ “ДНІПРОПЕТРОВСЬКА МЕДИЧНА АКАДЕМІЯ”
}

\author{
Yu. V. Kozlova, M. O. Kornilenko, S. I. Hmel’, M. A. Dovgal’, V. V. Koldunov, \\ N. S. Trjasak, G. A. Klopoc'kyj, O. Je. Hudjakov, A. Ju. Ljalina, G. M. Hmel'-Dunai \\ Dnipropetrovsk Medical Academy, Dnipro

\section{THE MEANING OF GENERAL AND PROFESSIONAL COMPETENCIES IN MASTER'S EDUCTION IN THE FIELD OF DENTISTRY AT THE DEPARTMENT OF PATHOLOGICAL PHYSIOLOGY OF THE DNIPROPETROVSK MEDICAL ACADEMY}

\begin{abstract}
Мета роботи - розкриття значення загальних та фахових компетентностей, які є основою нової робочої програми з патологічної фізіології для магістрів у галузі “Стоматологія”.

Основна частина. У статті наведено теоретичний аналіз загальних та фахових компетентностей з патофізіології і встановлено значущість їх впливу на підготовку магістра-стоматолога. Розкрито основні поняття та очікувані результати застосування орієнтовно-компетентнісного навчання. Показано важливість вивчення патологічної фізіології студентами-стоматологами, яка сприяє формуванню аналітичного мислення і сприйняття організму людини як єдиного цілого, розкриває основні поняття “здоров’я” та “хвороба”, встановлює взаємозв’язок між впливом патологічних чинників і захворюваннями, показує зв’язок соматичної патології зі стоматологічною й навпаки.

Висновки. Патофізіологія є міждисциплінарним предметом, що інтегрує теоретичні і клінічні дисципліни, та займає одне 3 провідних місць серед медичних дисциплін. Застосування компетентнісного підходу у викладанні патологічної фізіології для студентів стоматологічної галузі сприяє підготовці висококваліфікованого, всебічно освіченого компетентного фахівця, який може гармонійно поєднувати та використовувати на практиці всі необхідні знання та вміння.
\end{abstract}

Ключові слова: патологічна фізіологія; компетенція; вища медична освіта; магістр; стоматологія.

The aim of the work - to reveal the importance of general and professional competencies, which are the basis for the new working program on pathological physiology for masters in the field of Dentistry.

The main body. The article gives a theoretical analysis of general and professional competencies in pathophysiology and establishes their significance influence on the preparation of a master of dentistry. The basic concepts and expected results of the application of competence-based education are revealed. The importance of studying pathological physiology by students-dentists is shown, it contributes to the formation of the analytical thinking and perception of the human body as a whole organism, reveals the basic concepts of "health" and "disease", establishes the relationship between the influence of pathological factors and diseases, shows the connection between somatic and dental pathology.

Conclusions. Therefore, pathophysiology is an interdisciplinary subject that integrates theoretical and clinical disciplines; it takes one of the leading places among medical disciplines. The application of a competent approach in the teaching of pathological physiology for students in the dental industry promotes the preparation of a highly skilled, well-educated competent specialist who can combine and apply in practice all the necessary knowledge and skills in a harmonious way.

Key words: pathological physiology; competence; higher medical education; master’s degree; dentistry.

Вступ. Сучасний темп розвитку медицини, швидкість оновлення інформації породжують нові ви-

(ㄷ Ю. В. Козлова, М. О. Корніленко, С. І. Хмель та ін. моги до навчання та викладання в закладах вищої освіти. Застосування новітніх технологій у медицині сприяє підвищенню вимог до абітурієнтів i, 
ще більше, до студентів медичних вищих закладів освіти. Це, у свою чергу, сприяє сучасній модернізації освітнього процесу, завдяки чому виникає необхідність приділяти увагу не лише здобуттю теоретичних та практичних знань, а й розвитку особистісних, соціальних та психологічних якостей майбутнього лікаря (ініціативність, пристосованість до роботи в сучасних умовах) [1]. Наразі запровадження компетентнісно-орієнтованого підходу в медичній освіті є одним із найбільш ефективних для підвищення якості навчання, що, у свою чергу, сприяє підготовці висококваліфікованих спеціалістів у галузі “Стоматологія”.

Адже відомо, що саме компетентнісний підхід визначає результативно-цільову спрямованість освіти, що $є$ його безперечною перевагою над іншими підходами [2]. Тому необхідність включення компетентнісного підходу в систему медичної освіти визначається зміною освітньої парадигми як сукупності установок, цінностей, технічних засобів тощо, є характерною для нашого суспільства, відповідає сучасному науково-технічному розвитку та міжнародним вимогам.

Мета роботи - розкриття значення загальних та фахових компетентностей, які є основою нової робочої програми з патологічної фізіології для магістрів у галузі “Стоматологія”.

Основна частина. Власне компетентність, як інтегральне поняття, передбачає наявність у випускника медичного закладу вищої освіти таких якостей і рис, як вузькоспеціалізовані знання, практичні навички, спосіб мислення, які обумовлюють спроможність особистості сприймати та відповідати на індивідуальні й соціальні потреби, здатності реагувати на запити часу, використовувати набуті знання та уміння, сформовані цінності й ставлення в повсякденній діяльності лікаря [2]. Застосування компетентнісного підходу дозволяє акцентувати увагу на результатах освіти, при цьому як результат освіти розглядається не сума засвоєної інформації, а здатність, що є вкрай важливим, людини діяти у різних проблемних ситуаціях [2].

Аналізуючи компетентність, як сучасне поняття, можна виділити три її основні складники: професійну компетентність, пов’язану безпосередньо 3 професійною діяльністю; соціальну компетентність, яка реалізується у вмінні співпрацювати, організовувати спільну діяльність колективу задля досягнення цілей, брати на себе відповідальність за спільні результати; особистісну компетентність здатність до саморозвитку, самовдосконалення, са- мореалізації, прагнення до постійного підвищення своєї освітньої компетентності.

Наразі компетентність у широкому сенсі розуміється як ступінь соціальної та психологічної зрілості людини, яка передбачає певний рівень психічного розвитку особистості, психологічну готовність до виконання професійної діяльності, що дозволяє індивіду успішно функціонувати в суспільстві та інтегруватися в нього. Якщо розглянути у вузькому сенсі, то компетентність є діяльнісною характеристикою, мірою інтегрованості людини в професію, що, у свою чергу, передбачає певну світоглядну спрямованість особистості, ціннісне ставлення до діяльності та її предметів. Компетентність $є$ інтегративною, тобто поєднує особистий досвід і знання, мотивацію та цінності особистості.

Кінцевим результатом компетентнісного методу освіти є формування всебічно освіченого лікаря, здатного реалізувати отриману інформацію для вирішення практичних проблем.

Відокремлюючись від загальної медичної освіти, необхідно уточнити особливості застосування компетентнісного навчання в студентів стоматологічного факультету на кафедрі патологічної фізіології Дніпропетровської медичної академії. Відомо, що патофізіологія є дисципліною, що формує клінічне мислення у студентів стоматологічного факультету, тому і студентам і викладачам необхідно розуміти особливості компетенцій з патофізіології для підвищення рівня навчання та досягання високих результатів. Серед загальних компетенцій з патофізіології виділяють: здатність до абстрактного мислення, аналізу та синтезу; здатність вчитися і бути сучасно навченим; знання та розуміння предметної області та розуміння професії; здатність застосовувати знання у практичних ситуаціях [3].

У науці абстрактне мислення відіграє чільну роль, бо є тією базою, на основі якої здійснюється основна процедура пізнавальної діяльності - категоризація. За цим терміном фіксується одне з найбільш фундаментальних властивостей людського досвіду - когнітивні здібності, в першу чергу до класифікації, розподілу за групами, класами, розрядами, типами тощо, що упорядковують сприйняття світу і дозволяють передбачити об’єкти та інші сутності реального й уявного світу. У зв’ язку 3 цим абстрактне мислення часто називають науковим мисленням. Завдяки йому людина здатна встановлювати зв’язок між подіями, узагальнювати і розподіляти досвід, а також вибудовувати для себе загальну модель світу. 
Аналіз, синтез, порівняння, абстрагування, узагальнення, класифікація, конкретизація - це основні логічні операції, найважливіші загальноінтелектуальні вміння, багато з яких є методами пізнання в науці та освоєння стоматологічної освіти, які сприяють виявленню раціональних способів вирішення проблеми, у тому числі проблем, що супроводжують діяльність лікаря-стоматолога.

Очевидно, що під час вивчення патофізіології без оволодіння базовими абстрактно-логічними операціями неможливе формування клінічного мислення лікаря як такого. Це є ключовою умовою отримання повноцінної вищої освіти і формування професіонала в будь-якій галузі знання, зокрема стоматології.

Задля досягнення успіху у сфері діяльності фахівцю-стоматологу обов'язково необхідні знання та розуміння предметної області, розуміння професійної діяльності, що базуються на багатьох факторах, у том числі на здатності до пошуку, оброблення та аналізу інформації з різних джерел, умінні вчитися і оволодівати сучасними знаннями, використовувати як державну, так і іноземну мови в освітній діяльності, застосовувати сучасні методи й освітні технології навчання. У зв'язку зі швидкістю оновлення інформації та темпами розвитку стоматології, для спеціаліста вкрай важливо регулярно оновлювати знання, інтегрувати їх у професійну діяльність, нести відповідальність за професійний розвиток, бути здатним до подальшого професійного навчання 3 високим рівнем автономності [4].

Важко переоцінити важливість для лікарів будьякої спеціальності здатності застосовувати знання в практичних ситуаціях. Під цією компетенцією мається на увазі можливість реалізовувати спеціалізовані концептуальні знання, набуті у процесі навчання на кафедрі патологічної фізіології, інтегрувати їх у практику стоматолога та вміти розв'язувати складні задачі і проблеми, які виникають у професійній діяльності. Важливість формування соціальних компетентностей можна продемонструвати на необхідності для стоматолога, як професіонала, що взаємодіє не тільки з фахівцями, крім впроваджування знання в практику, вміти також донести власні висновки, знання та пояснення до нефахівців-пацієнтів, задля підтримання порозуміння між лікарем та пацієнтом, встановлення довірчих відносин, а отже, і покращити якість стоматологічного лікування [5].

Серед професійних компетенцій з патофізіології виділяють такі: оцінювання результатів лабораторних та інструментальних досліджень, встановлення клінічного діагнозу стоматологічного захворювання, визначення характеру та принципів лікування як стоматологічних, так і соматичних захворювань, визначення тактики ведення стоматологічного хворого при соматичній патології, опрацювання державної, соціальної та медичної інформації [6].

Розкриваючи зміст професійних компетентностей 3 патофізіології в освіті майбутнього стоматолога, слід підкреслити серед інших використання фахівцем знань про стандартні методики обстеження; алгоритми діагностики захворювань; алгоритми виділення провідних симптомів або синдромів; вміння проводити фізикальне обстеження хворого, що складають основу фахових знань, уніфікують методику обстеження, зменшують ризик помилок у професійній діяльності, дозволяють за мінімальний час обгрунтовано та правильно встановити клінічний діагноз стоматологічного захворювання [6].

Доповнюючи вищесказане, слід зазначити, що на сьогодні існує велика кількість допоміжних як інструментальних, так і лабораторних методів досліджень, що дозволяють розширити уявлення лікаря про захворювання, уточнити особливості його перебігу в конкретного пацієнта. Таким чином, лікарю-стоматологу необхідно вміти оцінювати результати лабораторних та інструментальних досліджень і передбачити можливість впливу інших патологій на ймовірність розвитку або безпосередньо перебіг стоматологічних захворювань. Таке уміння передбачає не лише наявність спеціалізованих знань про людину, її органи та системи, а й розуміння доцільності призначення досліджень, знання стандартної методики їх проведення, а також вміння аналізувати результати, зіставляючи їх 3 клінічною картиною, зробити відповідні висновки, нести відповідальність за прийняття рішення щодо оцінювання результатів. Основи такого вміння закладаються саме на кафедрі патологічної фізіології, адже тут навчають розуміти, які механізми порушення роботи систем організму обумовлюють специфічні клінічні прояви та дають уявлення про те, які маркери захворювання можуть бути виявлені під час проведення тих чи інших досліджень [6].

Використовуючи вміння до аналізу, синтезу та формування висновків, лікар-стоматолог безумовно має без труднощів визначати принципи та характер лікування захворювань. Мати спеціалізовані знання щодо алгоритмів та стандартних схем лікування захворювань, сформувати та донести до пацієнта та фахівців власні висновки щодо принципів і характеру лікування [7]. 
Зазначимо також, що магістр, а потім вже й спеціаліст-стоматолог у своїй практичній діяльності зустрічається постійно з супутньою патологією, що пояснює важливість усесторонньої загальнолікарської підготовки та уміння коректувати профільне лікування з урахуванням супутньої патології, розуміння механізмів взаємозв’ язку супутньої патології зі стоматологічною, основи якої закладаються під час вивчення патофізіології.

Крім вищезазначеного, під час вивчення патологічної фізіології, враховуючи кількість сучасних актуальних наукових медичних та соціальних досліджень, результати яких щоденно з'являються, на кафедрі пояснюють необхідність володіння навиком обробки державної, соціальної та стоматологічної інформації, включаючи сучасні комп’ютерні інформаційні технології, й закладають його основи, вчать вмінь визначати джерело, місцезнаходження потрібної інформації залежно від ії типу, отримувати необхідну інформацію з визначеного джерела, обробляти та аналізувати отриману інформацію [8]

Підсумовуючи, треба сказати, що під поняттям “компетентність” мається на увазі - динамічна комбінація знань, вмінь та практичних навичок, способів мислення, професійних, світоглядних і громадянських якостей, морально-етичних цінностей, які визначають здатність особи успішно здійснювати навчальну та подальшу професійну діяльність і $є$ результатом навчання на певному рівні. Компетентність включає в себе компетенції - інтегративне поняття, складовим якого є рівень знань, вмінь, здібностей, ініціатив особистості, що $€$ необхідними для ефективного виконання конкретної цілі і $є$ основою для подальшого формування та розвитку компетентності [9].

Основи всіх як загальних, професійних, соціальних, так і особистісних компетенцій закладаються

\section{Список літератури}

1. Learning analytics in medical education assessment: the past, the present, and the future / T. Chan, S. Sebok-Syer, B. Thoma [et al.] // AEM Education and Training. - 2018. 2 (2). - P. 178-187. doi:10.1002/aet2.10087.

2. Компетентнісний підхід у вищій освіті: світовий досвід / [Л. Л. Антонюк, Н. В. Василькова, Д. О. Ільницький та ін.]. - К. : КНЕУ, 2016. - 66 с.

3. Сапожниченко Л. В. Актуальні проблеми теоретичної та практичної підготовки студентів-медиків при вивченні циклу “Внутрішня медицина” на 6 курсі / Л. В. Сапожниченко, Ю. В. Козлова // Медична освіта. 2018. - № 3. doi: 10.11603/me.2414-5998.2018.3.8725.

4. Мандра Ю. В. Внедрение компетентностного подхода в подготовку врача-стоматолога / Ю. В. Мандра // Проблемы стоматологии. - 2013. - № 1. - С. 71-73. майбутніми лікарями-стоматологами під час здобуття вищої освіти, а дисципліна “Патофізіологія”, як інтегральна дисципліна на межі теоретичних та клінічних знань, бере в цьому безпосередню участь [3].

Загальні компетенції з патофізіології інтегрально характеризують окрему особистість не тільки за рівнем знань, вмінь та навиків, надають можливість отримувати досвід самостійної діяльності, вчать особистої відповідальності.

Фахові компетенції з патофізіології включають в себе необхідні вміння і знання в медицині, сприяють розвитку аналітичного та клінічного мислення, виховують етичне й гуманне ставлення до людей, розглядають поняття “здоров’я” та “хвороба” не тільки як особисте надбання, а й як соціальне і державне питання [10]. Окремо розглядаються питання збереження здоров'я та профілактики захворювань, й окремо - аспекти їх лікування.

Для впровадження сучасного компетентнісного підходу навчання на кафедрі патологічної фізіології ДМА було розроблено за Стандартом вищої освіти в галузі знань “Охорона здоров’я” 2016 року та затверджено на ЦМК ДМА робочу програму для студентів стоматологічного факультету.

Висновки. Патофізіологія $є$ міждисциплінарним предметом, що інтегрує теоретичні й клінічні дисципліни, та займає одне з провідних місць серед медичних дисциплін. Застосування компетентнісного підходу у викладанні патологічної фізіології для студентів стоматологічної галузі сприяє підготовці висококваліфікованого, всебічно освіченого компетентного фахівця, який може гармонійно поєднувати й використовувати на практиці всі необхідні знання та вміння.

5. Труфанова В. П. Роль практичного заняття у формуванні професійної компетенції лікаря за фахом “Дитяча стоматологія” / В. П. Труфанова // Український стоматологічний альманах. - 2017. - № 2. - С. 71-73.

6. Impact of community-based dental education on attainment of ADEA competencies: Students' self-ratings / K. K. McFarland, P. Nayar, D. Ojha [et al.] // Journal of Dental Education. - 2016. - Vol. 80 (6). - P. 670-676.

7. Andrews E. A. The future of interprofessional education and practice for dentists and dental education / E. A. Andrews // Journal of Dental Education. - 2017. Vol. 81 (8). - P. 186-192. doi.org/10.21815/JDE.017.026.

8. Hernández-de-Menéndez $M$. Current trends in competency based education. world journal of engineering and technology / M. Hernández-de-Menéndez, R. Morales- 
Menendez // Scientific Research Publishing Inc. - 2016. Vol. 4 (3). - P. 193-199. doi.org/10.4236/wjet.2016.43d023.

9. Whitney E. M. Critical thinking disposition and skills in dental students: development and relationship to academic outcomes / E. M. Whitney, J. Aksejuniene,

\section{References}

1. Chan, T., Sebok-Syer, S., Thoma, B., Wise, A., Sherbino, J., \& Pusic, M. (2018). Learning analytics in medical education assessment: The past, the present, and the future. AEM Education and Training, 2 (2), 178-187.

2. Antoniuk, L.L. (2016). Kompetentnisnyi pidhid u vyshhii osviti: svitovyi dosvid [Competence approach in higher education: global experience]. Vadym Hetman Institute of higher education, Kyiv: KNEU [in Ukrainian].

3. Sapozhnyzhenko, L.V., \& Kozlova, Yu.V. (2018). Aktualni problemy teoretychnoi ta praktychnoi pidhotovky studentiv-medykiv pry vyvchenni tsyklu "Vnutrishnia medytsyna” na 6 kursi [Actual problems of theoretical and practical training of medical students in the study of the cycle "Internal medicine" in the 6th year]. Medychna osvita Medical Education, 3, 67-69 [in Ukrainian]. DOI: https:// doi.org/10.11603/me.2414-5998.2018.3.8725.

4. Mandra, Yu.V. (2013). Vnedrenie kompetentnostnogo podhoda $\mathrm{v}$ podgotovku vracha stomatologa [Implementation of a competent approach to the training of a dentist]. Problemy stomatologii - Problems of Dentistry, 1, 71-73 [in Russian].

5. Trufanova, V.P. (2017). Rol praktychnoho zaniattia u formuvanni profesiinoi kompetentsii likaria za fakhom "Dytiacha Stomatolohiia” [The role of practical training in the formation of the professional competence of a
Joanne, N. Walton // Journal of Dental Education. - 2016. Vol. 80 (8). - P. 948-958.

10. Ідентифікація спеціальних компетентностей магістра в галузі стоматології: проект / Я. А. Кульбашна, О. О. Гудар’ян, В. В. Никонов, Н. Г. Ідашкіна // Медичні перспективи. - 2016. - № 4. - С. 23-27.

doctor in the specialty “Children's Dentistry]. Ukrainskyi stomatolohichnyi almanah - Ukrainian Dental Almanac, 2, 71-73 [in Ukrainian].

6. McFarland, K.K., Nayar, P., Ojha, D., Chandak, A., Gupta, N., \& Lange, B. (2016). Impact of community-based dental education on attainment of ADEA competencies: Students self-ratings. Journal of Dental Education, 80 (6), 670-676.

7. Andrews, E.A. (2017). The future of interprofessional education and practice for dentists and dental education. Journal of Dental Education, 81 (8), 186-192.

8. Hernández-de-Menéndez, M., \& Morales-Menendez, R. (2016). Current trends in competency based education. world journal of engineering and technology. Scientific Research Publishing, 4 (3), 193-199.

9. Whitney, E.M., Aleksejuniene, J., \& Walton, J.N. (2016). Critical thinking disposition and skills in dental students: development and relationship to academic outcomes. Journal of Dental Education, 80 (8), 948-958.

10. Kulbashna, Ja.A., Gudarian, O.O., Nykonov, V.V., \& Idashkina, N.G. (2016). Identyfikatsiia spetsialnykh kompetentnostei mahistra $\mathrm{v}$ haluzi stomatolohii: proekt [Identification of specialist skills in the field of dentistry: a project]. Medychni perspektyvy - Medical Perspectives, 4, 23-27 [in Ukrainian]. 